\section{Change in Tissue Mineral Elemental Concentration during Root Initiation and Development of Poinsettia Cuttings}

\author{
Sven E. Svenson and Fred T. Davies, Jr. ${ }^{1}$ \\ Department of Horticultural Science, Texas A\&M University, College Station, \\ TX 77843-2133 \\ Additional index words. adventitious root formation, ornamentals, vegetative propagation, \\ Euphorbia pulcherrima
}

\begin{abstract}
Variation in tissue elemental concentration in apical stem cuttings of 'Lilo' and 'V-10 Amy' poinsettia (Euphorbia pulcherrima Willd. ex. Klotzch) were studied during the initiation and development of adventitious roots. Changes in selected macro- and microelement concentrations coincided with root initiation (i.e., $\mathrm{Fe}, \mathrm{Cu}$, and $\mathrm{Mo}$ accumulated in the basal portions of stem cuttings during early root initiation before root primordia elongation); P, K, Ca, and Mg concentrations declined. During root primordia elongation and root emergence, $\mathrm{Fe}, \mathrm{Cu}$, and $\mathrm{Mo}$ and $\mathrm{Mg}, \mathrm{Mn}, \mathrm{B}$, and $\mathrm{Zn}$ concentrations continued to increase at the cutting bases, but $P$ and $K$ concentrations remained low compared to when cuttings were initially inserted in the propagation medium. When all cutting of both cultivars had rooted, foliar $\mathrm{N}$, Fe, and Mo concentrations declined, but $\mathrm{Cu}$ increased compared to when cuttings were initially propagated.
\end{abstract}

Adventitious root formation can be divided into two stages: 1 ) dedifferentiation and root initiation and 2) root growth and development (Hartmann et al., 1990). The first stage is critical for cuttings to root successfully. The significance of mineral element content on root growth and development has been recognized; however, the effect of specific mineral elements on dedifferentiation and root initiation remains unclear (Blazich, 1988). Previous studies provide an understanding of the role of mineral elements in later root growth and development; however, mineral elemental effects during the early developmental stages of adventitious root formation are less clear because of the difficulty in separating early endogenous root initiation from visible root growth and development.

Many elements are thought to be active in root induction, including $\mathrm{N}, \mathrm{P}, \mathrm{Ca}, \mathrm{Mg}, \mathrm{Mn}, \mathrm{B}$, and Zn (Anderson, 1986; Blazich, 1988).Zinc, $\mathrm{Mn}$, and $\mathrm{B}$ influence the metabolic status of indole-3-acetic acid (IAA) (Jarvis et al., 1984; Salami and Kenefick, 1970; Takaki and Kushizaki, 1970; Thomaszewski and Thimann, 1966). The Fe status of plants may be regu-

Received for publication 1 July 1994. Accepted for publication 22 Dec. 1994. Texas Agriculture Expt. Station Journal Series TA 31735. Identification of trade products used does not imply endorsement nor criticism of similar products not used. We greatly appreciate the critical reviews of T.D. Davis, J.E Preece, J.R. Potter, D.K. Struve, Y.T. Wang, D.C Wilkerson, and one anonymous reviewer. We gratefully acknowledge the technical assistance of S.A Duray and the donation of plant materials from the Paul Ecke Ranch, Encinitas, Calif. The cost of publishing this paper was defrayed in part by the payment of page charges. Under postal regulations, this paper therefore must be hereby marked advertisement solely to indicate this fact.

${ }^{1}$ To whom reprint requests should be addressed. lated partially by auxins (Mengel and Kirkby, 1982). Despite their importance, the role of micronutrient elements on adventitious root formation has received little attention (Hartmann et al., 1990; Jarvis et al., 1983; Reuveni and Raviv, 1980).

We are not aware of any reports on the effects of tissue elemental concentration on the discrete developmental stages of adventitious root formation in poinsettia. Our objective was to determine the changes in tissue elemental concentrations during early root initiation and later root development of poinsettia cuttings.

\section{Materials and Methods}

Stem cuttings ( $9 \mathrm{~cm}$ long) of 'Lilo' and ' $\mathrm{V}$ 10 Amy' poinsettias were inserted (basal 3 $\mathrm{cm})$ into 6-cm square pots $(420 \mathrm{ml})$ filled with $150 \mathrm{ml}$ of a fully moistened 3 perlite : 1 Canadian sphagnum peat (v/v) medium. The medium had been thoroughly leached with double-distilled water $\left(\mathrm{dd} \mathrm{H}_{2} \mathrm{O}\right)$. There were 150 cuttings per cultivar, which were randomly sampled during the experiment. The cuttings were watered-in with dd $\mathrm{H}_{2} \mathrm{O}$ after insertion into the propagation medium; this was the only time during the experiment that the lamina of the cuttings was exposed to irrigation water. Neither intermittent mist nor rooting compounds were used, and leaves were not removed from the basal stems of cuttings. Cuttings were rooted in a growth chamber under the following environment: relative humidity, $\geq 95 \%$, reduced to $80 \% \pm$ $8 \%$ after 15 days; $24 \mathrm{C}$, constant; $370 \pm 10 \mu \mathrm{l}$ ambient $\mathrm{CO}_{2}$ per liter air; 16-h photoperiod; photosynthetic photon flux of $180 \mu \mathrm{mol} \cdot \mathrm{m}^{-2} \cdot \mathrm{s}^{-1}$, increased to $250 \mu \mathrm{mol} \cdot \mathrm{m}^{-2} \cdot \mathrm{s}^{-1}$ after 15 days. The light was produced from a combination of 40- and 60-W incandescent lamps and cool- white fluorescent tubes (model FT96T12/CW/ VHO; Philips Lighting Co., Somerset, N.J.).

The pots with cuttings received $100 \mathrm{ml}$ Long-Ashton nutrient solution(LANS; Hewitt, 1966) without microelements on days 13 and 15 and daily thereafter. The modified LANS without microelements contained (in $\mathrm{mM}$ ) 4 $\mathrm{KNO}_{3}, 4 \mathrm{Ca}\left(\mathrm{NO}_{3}\right)_{2} \cdot 4 \mathrm{H}_{2} \mathrm{O}, 1.5 \mathrm{MgSO}_{4} \cdot 7 \mathrm{H}_{2} \mathrm{O}$, and $1.33 \mathrm{NaH}_{2} \mathrm{PO}_{4} \cdot 2 \mathrm{H}_{2} \mathrm{O}$.

Twelve randomly selected stem cuttings of each cultivar were harvested on days 1, 13 (before LANS application), and 23. The cuttings were separated into leaves and basal stem sections and oven-dried at $80 \mathrm{C}$ for 2 to 3 days. For elemental analysis, all nonsenescent leaves and 1-cm basal stem sections of 12 randomly selected plants per treatment were taken. The leaves and basal stem sections of three plants then were pooled for a single measurement with four pooled samples per treatment $(n=4)$. Samples were weighed and then ashed for determination (dry-mass basis) of percentage of $\mathrm{N}, \mathrm{P}, \mathrm{K}, \mathrm{Ca}$, and $\mathrm{Mg}$, and (in $\left.\mu \mathrm{g} \cdot \mathrm{g}^{-1}\right)$ of $\mathrm{Mn}, \mathrm{Fe}, \mathrm{B}, \mathrm{Cu}, \mathrm{Zn}$, and Mo on an inductively coupled plasma emission spectrometer (model 3510 ICP; Applied Research Laboratories, Dearborn, Mich.). Basal 1-cm stem sections from additional cuttings were sampled on days $1,5,9,13$, and 15 and were fixed in formalin-acetic acid-ethanol (FAA) in vacuo, embedded in Paraplast-plus after serial dehydration in ethanol-tertiary butyl alcohol, serially sectioned at $11 \mu \mathrm{m}$, stained with safranin and fast green, and then observed microscopically for root primordia formation(Davies et al., 1982).

The experiment was a completely randomized design, and data were tested for significant differences by cultivar and day using analysis of variance (SAS Institute, Cary, N.C.).

\section{Results}

The dry mass of leaves and the 1-cm basal stem sections (where adventitious roots originated) increased during rooting (Table 1). However, with both cultivars, the greatest percentage increase in dry mass occurred at the basal region of the stems. Between days 1 and 13, leaf and basal stem dry weight increased $40 \%$ and $96 \%$, respectively, for 'Lilo', and $70 \%$ and $50 \%$, respectively, for ' $\mathrm{V}-10$ Amy' (Table 1). Between days 13 and 23, leaf dry weight and basal stem dry weight increased $25 \%$ and $240 \%$, respectively, for 'Lilo', and $41 \%$ and $206 \%$, respectively, for ' $\mathrm{V}-10$ Amy'. 'Lilo' had more leaf dry mass than 'V10 Amy', but there were no cultivar differences in dry mass accumulation at the cutting bases.

Microscopic analysis indicated the presence of root primordia in the basal stems of both cultivars by day 13, but primordia elongation was absent (Table 1). By day 15, visible rooting was $85 \%$ and $70 \%$ for 'Lilo' and 'V-10 Amy', respectively, and by day 23 , all cuttings had rooted.

When root primordia initiation was first seen microscopically (day 13), both cultivars had lower foliar N, P, Fe, and Mo concentrations and higher $\mathrm{Cu}$ concentrations than on 
day 1 (Table 2). Foliar K and Mn concentrations were lower on day 13 than on day 1 for 'V-10 Amy', but not for 'Lilo'. At day 23, when all cuttings had rooted, foliar $\mathrm{N}, \mathrm{Ca}, \mathrm{Fe}$, and Mo concentrations were lower and $\mathrm{Cu}$ was higher compared to when cuttings were initially propagated (Table 2). Foliar Mn and B concentrations were lower relative to day 1 for 'V-10 Amy', but not for 'Lilo'. 'V-10 Amy' had higher foliar $\mathrm{P}$ and $\mathrm{Cu}$ but lower $\mathrm{Ca}, \mathrm{Mg}$, and Mn than 'Lilo'.

Iron, $\mathrm{Cu}$, and $\mathrm{Mo}$ concentrations were higher in the basal portion of stem cuttings during early root initiation (day 13 , before root primordia elongation and root emergence), but $\mathrm{P}, \mathrm{K}, \mathrm{Ca}$, and $\mathrm{Mg}$ levels declined (Table 2). During root primordia elongation and root emergence (after day 13 ), $\mathrm{Fe}, \mathrm{Cu}$, and $\mathrm{Mo}$ and $\mathrm{Mg}, \mathrm{Mn}, \mathrm{B}$, and $\mathrm{Zn}$ concentrations continued to increase at the cutting base, but $\mathrm{P}$ and $\mathrm{K}$ levels remained low compared to when cuttings were initially placed in the medium. 'V-10 Amy' had higher basal stem elemental concentrations of $\mathrm{P}, \mathrm{Ca}, \mathrm{Mg}, \mathrm{Mn}$, and $\mathrm{Cu}$ than 'Lilo' cuttings after 13 days.

\section{Discussion}

To our knowledge, this study is one of the first to report on changes in the mineral elemental concentration during the discrete developmental events of adventitious root formation of poinsettia cuttings. Elemental mineral content at the base of cuttings (reported on a dry-mass basis) must be interpreted carefully because an increase in cutting dry mass can dilute the concentration of a particular element (Blazich, 1988). Concentration dilutions resulting from increases in dry mass may be important for normal development of adventitious roots. The two cultivars averaged a
$73 \%$ increase in basal stem dry mass of cuttings when root primordia were first viewed microscopically (day 13) and a $223 \%$ increase by the time all cuttings had rooted (day 23). Despite the increasing tissue mass, $\mathrm{Fe}, \mathrm{Cu}$, and Mo concentrations had increased at the basal portion of cuttings when primordia were first observed, and by day $23, \mathrm{Mg}, \mathrm{Mn}, \mathrm{B}$, and $\mathrm{Zn}$ also had increased. The cuttings were fertilized after measurements were taken on day 13; however, only tissue macroelements should have been affected because LANS was applied without microelements. By day 23, tissue $\mathrm{P}$ and $\mathrm{K}$ levels were low at the base of cuttings compared to tissue levels when cuttings were first inserted into the medium.

Leaf mass and leaf area also increased (data not reported) (Svenson et al., 1995). There was a general decrease in foliar elemental concentration of $\mathrm{N}, \mathrm{Fe}$, and Mo, which could have resulted from a concentration dilution caused by increased dry mass. Foliar leaching of cuttings (Wott and Tukey, 1967) was probably not a factor because the cuttings were not misted and there was no decrease in total tissue elemental content. For 'V-10 Amy', $B$ may have been reallocated from the apical portion of the cutting stem into the basal stem and leaves, active growth and potential sink areas. Although B generally is considered an immobile element, sufficient B may be translocated from shoots to support rapid root growth (Oertli, 1993). Decreased foliar and increased basal-stem tissue concentrations suggest that $\mathrm{Fe}$ and Mo were being reallocated during rooting. An increase in dry mass concurrent with an increase in mineral element concentration for a particular section of a cutting provides evidence for redistribution of mineral elements within the cutting.

Although mineral element content of the rooting medium was not tested, the leachate conductivity from pots did not differ from the conductivity of the added $\mathrm{dd}_{2} \mathrm{O}$ used to leach the medium. The content and availability of micronutrients in peat is low (Bunt, 1988), and it is doubtful that the 3 perlite : 1 Canadian sphagnum peat medium contributed to any

Table 1. Dry weight of leaf and 1-cm basal stem sections of stem cuttings during adventitious root formation of 'Lilo' and 'V-10 Amy' poinsettias over 23 days.

\begin{tabular}{lccccc}
\hline \hline Cultivar & Day & $\begin{array}{c}\text { Leaf } \\
\text { dry wt } \\
(\mathrm{mg})\end{array}$ & $\begin{array}{c}\text { Basal stem } \\
\text { dry wt } \\
(\mathrm{mg})\end{array}$ & $\begin{array}{c}\text { Root } \\
\text { primordia } \\
\text { initiated }\end{array}$ & $\begin{array}{c}\text { Root } \\
\text { primordia } \\
\text { elongation }\end{array}$ \\
\hline Lilo & 1 & $433 \pm 3^{2}$ & $30 \pm 0$ & No & No \\
& 13 & $605 \pm 4$ & $59 \pm 1$ & Yes & No \\
V-10 Amy & 23 & $753 \pm 3$ & $209 \pm 2$ & Yes & Yes \\
& 13 & $256 \pm 3$ & $39 \pm 0$ & No & Yo \\
Significance & 23 & $436 \pm 3$ & $62 \pm 1$ & Yes & Yes \\
Cultivar & & $614 \pm 7$ & $190 \pm 4$ & & \\
Day & & $* * *$ & & & \\
\hline
\end{tabular}

${ }^{\mathrm{z}}$ Mean and SE $(\mathrm{n}=10)$.

ss, ****Nonsignificant or significant at $P \leq 0.001$, respectively; cultivar $\times$ day interactions were nonsignificant.

Table 2. Mineral element concentrations of leaves and lower stem sections of cuttings of 'Lilo' and 'V-10 Amy' poinsettias during adventitious root formation over time. Root primordia were initiated by day 13, and root primordia elongation was completed by day 23 .

\begin{tabular}{|c|c|c|c|c|c|c|c|c|c|c|c|c|}
\hline Cultivar & Day & $\begin{array}{c}\mathrm{N} \\
(\%)\end{array}$ & $\begin{array}{c}\mathrm{P} \\
(\%)\end{array}$ & $\begin{array}{c}\mathrm{K} \\
(\%) \\
\end{array}$ & $\begin{array}{l}\mathrm{Ca} \\
(\%)\end{array}$ & $\begin{array}{l}\mathrm{Mg} \\
(\%)\end{array}$ & $\begin{array}{c}\mathrm{Mn} \\
\left(\mu g \cdot g^{-1}\right)\end{array}$ & $\begin{array}{c}\mathrm{Fe} \\
\left(\mu \mathrm{g} \cdot \mathrm{g}^{-1}\right)\end{array}$ & $\begin{array}{c}\mathrm{Cu} \\
\left(\mu \mathrm{g} \cdot \mathrm{g}^{-1}\right)\end{array}$ & $\begin{array}{c}\text { B } \\
\left(\mu g \cdot g^{-1}\right)\end{array}$ & $\begin{array}{c}\mathrm{Zn} \\
\left(\mu \mathrm{g} \cdot \mathrm{g}^{-1}\right)\end{array}$ & $\begin{array}{c}\text { Mo } \\
\left(\mu g \cdot g^{-1}\right)\end{array}$ \\
\hline \multicolumn{13}{|c|}{ Leaves z } \\
\hline \multirow[t]{3}{*}{ Lilo } & 1 & $3.40 \pm 0.10$ & $0.35 \pm 0.02$ & $1.86 \pm 0.09$ & $0.55 \pm 0.02$ & $0.32 \pm 0.02$ & $74.3 \pm 12.2$ & $82.7 \pm 7.4$ & $21.5 \pm 1.0$ & $18.6 \pm 1.2$ & $39.1 \pm 4.0$ & $1.24 \pm 0.03$ \\
\hline & 13 & $2.85 \pm 0.09$ & $0.32 \pm 0.01$ & $1.70 \pm 0.03$ & $0.50 \pm 0.07$ & $0.32 \pm 0.03$ & $88.6 \pm 5.8$ & $77.8 \pm 4.2$ & $24.6 \pm 1.2$ & $17.4 \pm 1.3$ & $34.4 \pm 2.7$ & $1.15 \pm 0.09$ \\
\hline & 23 & $2.63 \pm 0.34$ & $0.32 \pm 0.03$ & $2.61 \pm 0.20$ & $0.46 \pm 0.03$ & $0.33 \pm 0.02$ & $61.6 \pm 6.4$ & $62.1 \pm 3.9$ & $28.6 \pm 2.6$ & $16.9 \pm 1.4$ & $31.0 \pm 2.3$ & $>0.05$ \\
\hline \multirow[t]{4}{*}{ V-10 Amy } & 1 & $4.13 \pm 0.12$ & $0.51 \pm 0.02$ & $2.53 \pm 0.07$ & $0.45 \pm 0.07$ & $0.28 \pm 0.02$ & $70.1 \pm 14.8$ & $80.9 \pm 2.9$ & $26.4 \pm 1.3$ & $20.6 \pm 1.9$ & $42.7 \pm 0.8$ & $1.25 \pm 0.04$ \\
\hline & 13 & $2.98 \pm 0.18$ & $0.37 \pm 0.02$ & $1.67 \pm 0.03$ & $0.28 \pm 0.03$ & $0.18 \pm 0.01$ & $34.2 \pm 4.9$ & $62.8 \pm 5.7$ & $33.9 \pm 1.9$ & $13.8 \pm 0.8$ & $37.3 \pm 1.9$ & $1.01 \pm 0.08$ \\
\hline & 23 & $3.13 \pm 0.37$ & $0.39 \pm 0.02$ & $2.42 \pm 0.35$ & $0.29 \pm 0.05$ & $0.21 \pm 0.03$ & $33.8 \pm 4.8$ & $58.4 \pm 7.7$ & $48.3 \pm 1.4$ & $13.0 \pm 2.1$ & $36.7 \pm 1.9$ & $0.55 \pm 0.02$ \\
\hline & \multicolumn{12}{|c|}{ Basal stem ${ }^{y}$} \\
\hline \multirow[t]{3}{*}{ Lilo } & 1 & $2.35 \pm 0.26$ & $0.41 \pm 0.02$ & $4.20 \pm 0.11$ & $0.39 \pm 0.02$ & $0.19 \pm 0.01$ & $46.0 \pm 9.0$ & $42.7 \pm 4.0$ & $4.5 \pm 0.5$ & $11.0 \pm 0.3$ & $24.7 \pm 0.4$ & $1.53 \pm 0.04$ \\
\hline & 13 & $2.30 \pm 0.13$ & $0.29 \pm 0.01$ & $2.59 \pm 0.05$ & $0.25 \pm 0.01$ & $0.11 \pm 0.01$ & $53.6 \pm 3.4$ & $69.4 \pm 4.5$ & $7.9 \pm 0.1$ & $10.1 \pm 0.3$ & $26.3 \pm 1.5$ & $1.82 \pm 0.14$ \\
\hline & 23 & $2.88 \pm 0.11$ & $0.35 \pm 0.02$ & $2.79 \pm 0.26$ & $0.50 \pm 0.04$ & $0.34 \pm 0.03$ & $269.8 \pm 21.5$ & $355.5 \pm 48.1$ & $15.2 \pm 1.3$ & $50.2 \pm 3.6$ & $33.9 \pm 2.9$ & $3.83 \pm 0.16$ \\
\hline \multirow[t]{3}{*}{ V-10 Amy } & 1 & $3.98 \pm 0.24$ & $0.56 \pm 0.02$ & $4.12 \pm 0.16$ & $0.71 \pm 0.08$ & $0.20 \pm 0.01$ & $126.3 \pm 13.0$ & $59.3 \pm 1.6$ & $7.9 \pm 0.7$ & $10.3 \pm 0.4$ & $33.3 \pm 2.5$ & $1.81 \pm 0.06$ \\
\hline & 13 & $2.93 \pm 0.14$ & $0.38 \pm 0.01$ & $2.47 \pm 0.17$ & $0.61 \pm 0.01$ & $0.16 \pm 0.01$ & $105.0 \pm 16.8$ & $91.8 \pm 5.0$ & $10.3 \pm 1.6$ & $11.9 \pm 0.4$ & $32.4 \pm 0.8$ & $1.99 \pm 0.07$ \\
\hline & 23 & $3.08 \pm 0.20$ & $0.39 \pm 0.01$ & $2.78 \pm 0.12$ & $0.65 \pm 0.04$ & $0.53 \pm 0.06$ & $293.0 \pm 14.8$ & $409.8 \pm 48.1$ & $20.9 \pm 3.0$ & $49.2 \pm 1.5$ & $42.2 \pm 2.2$ & $3.68 \pm 0.21$ \\
\hline
\end{tabular}

Leaves

Cultivar (C)
Day (D)
C $\times$ D
Basal stem
C
D
C $\times$ D

$\begin{array}{lc}\text { NS } & * \\ * & * * \\ \text { NS } & \text { NS } \\ & \\ \text { NS } & * \\ * & * * * \\ * & *\end{array}$
Significance ${ }^{x}$

${ }^{2}$ All leaves from three cuttings pooled to make one sample; means and SE are from four samples $(n=4)$

$\begin{array}{ccccccc}* * & * * & \text { NS } & * * & \text { NS } & \text { NS } & \text { NS } \\ \text { NS } & \text { NS } & * & * * * & \text { NS } & \text { NS } & * * * \\ \text { NS } & * * & \text { NS } & * * & \text { NS } & \text { NS } & * \\ & & & & & & \\ * * & * & \text { NS } & * & \text { NS } & * & \text { NS } \\ * * * & * * * & * * * & * * * & * * * & * * & * * * \\ * * & \text { NS } & \text { NS } & \text { NS } & \text { NS } & \text { NS } & \text { NS }\end{array}$

y Basal 1-cm stem section from three cuttings pooled to make one sample; means and sE are from four samples $(\mathrm{n}=4)$.

Ns, *,**,*** Nonsignificant or significant at $\mathrm{P} \leq 0.05,0.01$, or 0.001 , respectively. 
significant increase in cutting tissue macroand microelements (J.W. Boodley, personal communication).

With both cultivars, change in selected macro- and microelemental concentrations coincided with early root initiation. Iron, $\mathrm{Cu}$, and Mo concentrations increased in the basal portions of unrooted stem cuttings during the root initiation stage, suggesting that concentrations of these elements may be important for early root primordia formation or other concurrent growth processes. Subsequent root primordia elongation (after day 13) potentially was influenced by these elements and increased concentrations of $\mathrm{Mg}, \mathrm{Mn}, \mathrm{B}$, and $\mathrm{Zn}$. Moderate $\mathrm{Cu}$ concentrations have increased root initiation and root elongation during in vitro rooting of birch microcuttings (Arnold, et al., 1994). Although it is generally agreed that $\mathrm{Fe}$ is not mobile in plants (Mengel and Kirkby, 1982), Fe seemed to be mobile under the conditions of this study. Blazich et al. (1983) reported a similar response for $\mathrm{Ca}$ mobility in Ilex crenata Thunb. 'Convexa' stem cuttings. The Fe and Mo accumulation at the root initiation site may help support nitrogenase and $\mathrm{NO}_{3}$ reductase activity on subsequent root growth and development (Mengel and Kirkby, 1982).

Zinc can promote the formation of the auxin precursor, tryptophan, and the formation of auxin from tryptophan (Salami and Kenefick, 1970; Takaki and Kushizaki, 1970). Conversely, Mn acts as an activator of the IAA-oxidase enzyme system (Thomaszewski and Thimann, 1966), and B may enhance IAAoxidase activity (Jarvis et al., 1984). Higher endogenous auxin levels are required for early root initiation than for later root development
(Hartmann et al., 1990). If root initiation is related to the relative activity of IAA and IAAoxidase, then rooting may be correlated with the relative $\mathrm{Zn}, \mathrm{Mn}$, and $\mathrm{B}$ concentrations at the site of root initiation. An analysis of IAA and IAA-oxidase activity concurrent with selected microelement concentrations during root initiation is needed to confirm or reject the hypothesis that relative concentrations of macro- and microelements at the site of root initiation can influence the discrete developmental stages of adventitious root formation in poinsettia cuttings.

\section{Literature Cited}

Anderson, A.S. 1986. Environmental influences on adventitious rooting in cuttings of non-woody species, p. 223-253. In: M.B. Jackson (ed.). New root formation in plants and cuttings. Martinus Nijhoff Publishers, Boston.

Arnold, M.A., R.D. Lineberger, and D.K. Struve. 1994. Copper compounds influence in vitro rooting of birch microcuttings. J. Amer. Soc. Hort. Sci. 119:74-79.

Blazich, F.A. 1988. Mineral nutrition and adventitious rooting, p. 61-69. In: T.D. Davis, B.E Haissig, and N. Sankhla (eds.). Adventitious root formation in cuttings. Dioscorides Press, Portland, Ore.

Blazich, F.A., R.D. Wright, and H.E. Schaffer. 1983. Mineral nutrient status of 'Convexa' holly cuttings during intermittent mist propagation as influenced by exogenous auxin application. J. Amer. Soc. Hort. Sci. 108:425-429.

Bunt, A.C. 1988. Media and mixes for container grown soils. Unwin Hyman, London.

Davies, F.T., Jr., J.E. Lazarte, and J.N. Joiner. 1982. Initiation and development of roots in juvenile and mature leaf bud cuttings of Ficus pumila $\mathrm{L}$. Amer. J. Bot. 69:804-811.
Hartmann, H.T., D.E. Kester, and F.T. Davies, Jr. 1990. Plant propagation-Principles and practices. Prentice Hall, Englewood Cliffs, N.J.

Hewitt, E.J. 1966. Sand and water culture methods used in the study of plant nutrition. 2nd ed. Commonwealth Agricultural Bureaux, Farnham Royal, England.

Jarvis, B.C., A.H.N. Ali, and R. Hunt. 1983. Auxin and boron in relation to the rooting response and aging of mung bean cuttings. New Phytol. 97:509-518.

Jarvis, B.C., A.H.N. Ali, and R. Hunt. 1984. The interaction between auxin and boron in adventitious root development. New Phytol. 97:197204.

Mengel, K. and E.A. Kirkby. 1982. Principles of plant nutrition. International Potash Inst., Bern, Switzerland.

Oertli, J.J. 1993. The mobility of boron in plants. Plant \& Soil 155/156:301-304

Reuveni, O. and M. Raviv. 1980. Importance of leaf retention to rooting of avocado cuttings. J. Amer. Soc. Hort. Sci. 106:127-130.

Salami, A.U. and D.G. Kenefick. 1970. Stimulation of growth in zinc-deficient corn seedlings by the addition of tryptophan. Crop Sci. 10:291294.

Svenson, S.E., F.T. Davies, Jr., and S.A. Duray. 1995. Gas exchange, water relations, and dry weight partitioning during root initiation and development of poinsettia cuttings. J. Amer. Soc. Hort. Sci. 120:454-459.

Takaki, H. and M. Kushizaki. 1970. Accumulation of free tryptophan and tryptamine in zinc deficient maize seedlings. Plant Cell Physiol. 11:793804.

Thomaszewski, M. and K.V. Thiman. 1966. Interaction of phenolic acids, metallic ions and chelating agents on auxin-induced growth. Plant Physiol. 41:1433-1454.

Wott, J.A. and H.B. Tukey, Jr. 1967. Influence of nutrient mist on the propagation of cuttings. Proc. Amer. Soc. Hort. Sci. 90:454-461. 